\title{
The Dynamics of Sphagnum in Forest and Peatland Communities in Southeastern Labrador, Canada
}

\section{Citation}

Foster, D. R. 1984. The dynamics of Sphagnum in forest and peatland communities in Southeastern Labrador, Canada. Arctic 37: 133-140.

\section{Published Version}

http://www.jstor.org/stable/40510266

\section{Permanent link}

http://nrs.harvard.edu/urn-3:HUL.InstRepos:30678840

\section{Terms of Use}

This article was downloaded from Harvard University's DASH repository, and is made available under the terms and conditions applicable to Other Posted Material, as set forth at http:// nrs.harvard.edu/urn-3:HUL.InstRepos:dash.current.terms-of-use\#LAA

\section{Share Your Story}

The Harvard community has made this article openly available.

Please share how this access benefits you. Submit a story.

Accessibility 


\title{
The Dynamics of Sphagnum in Forest and Peatland Communities in Southeastern Labrador, Canada
}

\author{
DAVID R. FOSTER'
}

\begin{abstract}
Long fire rotation, high levels of precipitation, and acidic nature of the bedrock are factors contributing to the dominance of Sphagnum in many upland and peatland communities in southeastern Labrador. Vegetation development induced by local or regional environmental change frequently involves replacement of species assemblages of various bryophytes and lichens by species assemblages dominated by Sphagnum. In upland forests the successional sequence following fire often culminates in a carpet of Sphagnum girgensohnii overgrowing feather mosses. Similarly, following a change in the water tabie, Sphagnum lindbergii encroaches as a broad carpet over Cladopodiella fluitans and Gymnocolea inflata on recently exposed mud bottoms in bog hollows. On bog hummocks, following fire or changes in the moisture regime, Sphagnum fuscum overtops Cladonia lichens to form a pronounced recurrence horizon.
\end{abstract}

Key words: Sphagnum, vegetation development, fire, Labrador, paludification, succession, bryophytes

RÉSUMÉ. Une longue rotation d'incendies, des taux élevés de précipitation et la nature acide du sousbassement sont tous des facteurs contribuant à la dominance du Sphagnum dans de nombreuses communautés de terre élevées et de tourbières dans le sud-est du Labrador. La croissance de la végétation provoquée par des changements locaux ou régionaux dans le milieu comprend souvent le remplacement d'établissements d'espéces de divers bryophytes et lichens par des établissements d'especces dominées par le Sphagnum. Dans les forêts des collines, la séquence de succession suivant un incendie se termine souvent par un tapis de Sphagnum girgensohnii poussant au-dessus de mousses hypnées. De même, suivant un changement dans le niveau hydrostatique, le Sphagnum lindbergii empiète comme un large tapis au-dessus des Cladopodiella fluitans et des Gymnocolea inflata sur des fonds boueux récemment exposés dans des creux de tourbières. Sur les tertres de tourbières, après un incendie ou un changement dans le régime d'humidité, le Sphagnum fuscum croît par-dessue les lichens Cladonia pour former un "horizon de retour" prononcé.

Mots clés: Sphagnum, croissance de la végétation, incendie, Labrador, formulation de paluds, succession, bryophytes

Traduit pour le journal par Maurice Guibord.

\section{INTRODUCTION}

Under the environmental conditions of the boreal region diverse Sphagnum species thrive and assume prominence in various upland and wetland plant communities. Because of their relatively rapid growth rate and inhibitory effect on decompositional processes, Sphagnum spp. are primary builders of peat and frequently of the forest organic layer.

Members of this genus produce relatively short horizontally spreading branches. Colonies frequently tend to have great coherence and individual plants tend to absorb prodigious quantities of water by means of the unique hyaline cells that are characteristic of the genus. The shoots act as wicks, drawing water up the exterior of each individual stem in spaces between the stem and leaves, and between adjacent shoots (Gimingham and Birse, 1957; Birse, 1958). Physiologically, Sphagnum can exchange $\mathrm{H}+$ ions for other cations at exchange sites composed of unesterified poly-uronic acids located on the cell walls (Clymo, 1963).

As a result of their particular morphological and physiological qualities, and their ability to produce significant organic accumulations, Sphagnum spp. may exert a pronounced influence on local soil environment, including temperature regime and permafrost development (Drury, 1956; Viereck, 1966), pH (Clymo, 1964), aeration (Andrus, 1974), water content (Heinselman, 1970, 1972), nutrient status (Heilman, 1966; Moizuk and Livingstone, 1966), and microfloral and microfaunal populations (Waksman, 1930; Rosswell et al., 1975). These effects may indirectly govern such important community attributes and processes as the direction and rate of vegetation development, productivity, nutrient cycling, floristic composition, and the nature and rate of export of materials into local catchment basins.

Labrador's cool maritime climate, regional geology, and physiography provide environments that are particularly conducive to the accumulation of organic deposits. The predominance of organic terrain on the extensive glacial plains and drumlin fields in southeastern Labrador has given this region the reputation of being 20-30\% covered by wetlands (Hare, 1959). These relatively level surfaces support a variety of peatlands including extensive patterned fens, large mire complexes, and, towards the coast, magnificent raised bogs (Foster, 1983a, 1983b; Foster and King, 1984; Glaser and Foster, 1984). As a result of the acidic nature of the bedrock and till, even the soligenous areas are characterized by oligotrophic groundwater with low $\mathrm{pH}$ and low concentrations of salts, conditions that favor the growth of Sphagnum.

Upland forest areas exhibit a fire rotation (sensu Heinselman, 1973) of considerably longer duration than that estimated for the rest of the North American boreal forest (Foster, 1983a). The long interval between fires (often exceeding 500 years) provides a period of vegetation development during which the forest floor becomes separated from the mineral substratum by a thick, water-logged organic soil with low $\mathrm{pH}$ (Foster, 1984b). During this process of paludification, environmental conditions gradually change to favor an increase of Sphagnum, which eventually blankets the forest floor.

Upland and wetland communities exhibit changes over time in structure, composition, and function, mediated by such en-

'Limnological Research Center, University of Minnesota, Minneapolis, Minnesota 55455, U.S.A. Present address: Harvard University, Harvard Forest, Petersham, Massachusetts 01366, U.S.A. 
vironmental factors as fire and long-term climatic change. As Sphagnum spp. are prominent in both types of habitat, vegetation development frequently involves the replacement of species assemblages with other growth forms by species assemblages dominated by Sphagnum. Observations of this process in southeastern Labrador suggest that this replacement sequence finds parallels in a variety of habitats in which various species groups are involved. As many studies suggest that Sphagnum is of critical importance in vegetation development (Lewis and Dowding, 1926; Wenner, 1947; Tansley, 1949; Swan and Gill, 1970; Walker, 1970; Vitt et al., 1975), an investigation of Sphagnum succession should help to elucidate the long-term dynamics of these communities and the role that individual Sphagnum species play in community development.

\section{METHODS}

The environment conducive to Sphagnum growth inhibits microbial activity and this property is enhanced by the physiological characteristics of the mosses. The result is incomplete decomposition of plant remains and preservation of a subfossil record of vegetation development over time. Thus one can relate present community composition and distribution of individual species to historical conditions. This procedure provides a record of the growth and spread of Sphagnum species to confirm the dynamics and processes inferred from the present landscape.

Following extensive phytosociological and paleoecological investigations in southeastern Labrador (Foster, 1983b, 1984a; Foster and King, 1984; Glaser and Foster, 1984) three habitats were chosen to form the basis of this study on Sphagnum succession. These include a 110-year-old black spruce-Pleurozium forest (cf. Foster, 1984a) along the Alexis River, a Sphagnum lindbergii-Carex limosa mud-bottom community (cf. Foster and King, 1984), and a Sphagnum-fuscum hummock community (cf. Glaser and Foster, 1984), the last two in a large plateau bog occupying an outwash terrace on the Gilbert River. The selected sites are representative of the three communities as described in previous investigations.

In each community chosen for stratigraphic analysis the vegetation was sampled in three relevés according to methods developed by the Braun-Blanquet school of phytosociology (Mueller-Dombois and Ellenberg, 1974). All species were recorded within $20 \times 20 \mathrm{~m}$ plots in forested areas (sprucePleurozium forest), and in $10 \times 10 \mathrm{~m}$ plots in open areas of treeless vegetation (bog hummock and hollows). Visual estimates of cover abundance were assigned on a standard 7-point scale. Complete sets of voucher specimens of lichens and vascular species are stored in the University of Minnesota herbarium, and bryophytes at the National Museum of Natural Sciences, Ottawa. Nomenclature follows Ireland et al. (1980) for mosses, Stotler and Crandall-Stotler (1977) for hepatics, and Hale and Culberson (1970) for lichens, with the exception of Cladonia which follows Ahti (1961).

In each relevé plot two excavations were made with a serrated knife to expose the stratigraphic relationships of the cryptogams and to cut monoliths for laboratory examination. The depth and length of exposure varied with the growth habit of the species and the nature of the habitat. Photographs were taken of the monoliths and pits. Samples were wrapped in plastic and aluminum foil for transfer to the lab.

\section{SPHAGNUM SUCCESSION IN UPLAND FOREST}

Following fire in the upland spruce-Pleurozium forest (Table 1), there ensues a long period of vegetation development that leads to the reestablishment of a closed-canopy community (Foster, 1984b). The following sequence is documented: Lecidea granulosa - Polytrichum juniperinum horn and cup fruticose lichens (Cladonia sulphurina, $C$. chlorophaea, $C$. gracilis, $C$. coccifera) - larger fruticose lichens (Cladonia mitis, C. rangiferina, C. stellaris) - feather mosses (Pleurozium schreberi, Ptilium crista-castrensis, Hylocomium splendens) - Sphagnum girgensohnii (Foster, 1984b).

The cover of feather mosses is related to the degree of canopy closure, as these species depend on the increased nutrient availability and humidity found within the shade of the conifers (Tamm, 1953). The completion of the outlined sequence depends on the fire interval in a specific locality. In particular, the transition from feather moss to Sphagnum girgensohnii requires long periods (100-200 years) and the accumulation of a moist, acidic mor humus (Foster, 1983a, 1984b).

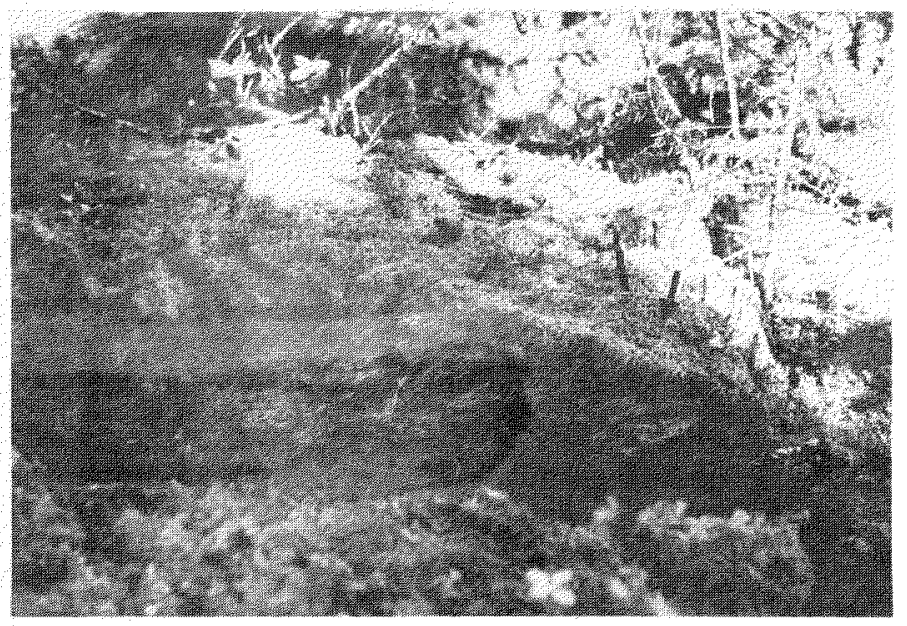

FIG. 1. Cross-section through a thick blanket of Sphagnum girgensohnii, illustrating the abrupt margin of the advancing Sphagnum. Note the alignment of the shoots: vertical at the center of the clump (on left of photo) and gradually becoming oblique to horizontal towards the front edge (arrow). The pencil provides scale.

Once established, Sphagnum girgensohnii grows rapidly. Hollows and similar depressions in the forest floot present moist micro-habitats where conditions are optimal for Sphagnum colonization, and these serve as nuclei from which the plant spreads rapidly outward (cf. Drury, 1956). Sphagnum's ramifying form and rapid growth cause it to overtop the feather mosses, smothering them beneath an expanding "wave" (Fig. 1). A typical wave of $S$. girgensohnii is approximately $2-3 \mathrm{~cm}$ thick at the edge and progressively deeper 
TABLE 1. Phytosociological table of communities discussed in text. Cover abundance values: $r=1$ individual; $+=$ occasional; $1=<5 \%$; $2=5-20 \% ; 3=20-50 \% ; 4=50-70 \% ; 5=>70 \%$.

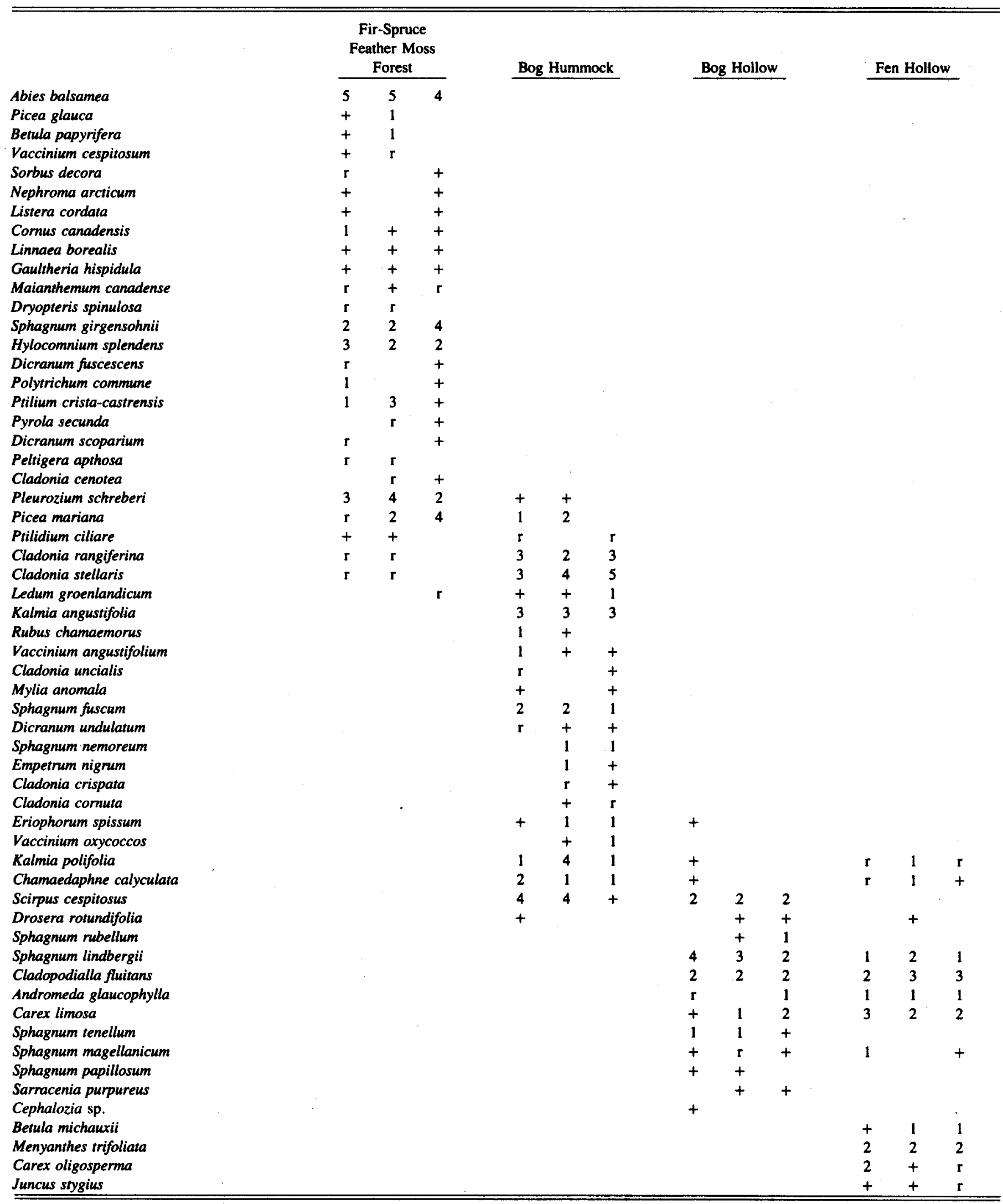


(15-20 $\mathrm{cm}$ maximum) towards the center of the hollow in which growth started (Fig. 2).
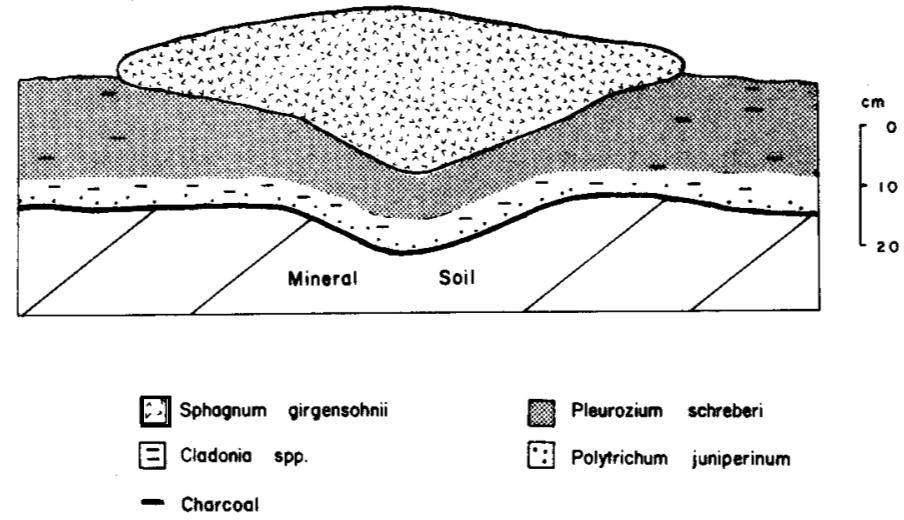

FIG. 2. Profile of the mor humus layer in a 110-year-old forest, cut through a Sphagnum girgensohnii clump. The humus stratigraphy provides evidence of the post-fire change in ground cover. Sphagnum growth commenced in the depression and subsequently spread laterally outward.

In cross-section it is apparent from the oblique alignment of the Sphagnum stems that growth is simultaneously vertical and radial. Studies in paludified forests in Finland demonstrate that annual increment and average annual production are significantly greater for Sphagnum girgensohnii than for feather mosses (Pakarinen and Rinne, 1979), allowing it to overtop and blanket these late-successional species. The outward growth of Sphagnum girgensohnii from scattered depressions continues until individually expanding clones meet and coalesce. With time, the proportion of Sphagnum cover increases at the expense of feather mosses and ultimately produces a thick continuous carpet.

Similar bryophyte replacement series are apparent across the boreal forest and are documented in Alaska (Drury, 1956; Heilman, 1966; Viereck, 1970), northern Minnesota (Heinselman, 1963, 1970), northern Michigan (Cooper, 1912), Quebec and Ontario (Auer, 1933), Alberta (Lewis and Dowding, 1926; Lewis et al., 1928), and Fennoscandia (Sirén, 1955). As Sphagnum assumes dominance, there occurs an increase in the thickness and moisture content of the organic horizon and a concomitant decrease in $\mathrm{pH}$, soil temperature, decomposition rates, nutrient availability, and stand productivity (Foster, 1983a).

The changing environmental regime favors more oligotrophic vascular species; and a progressive change occurs in community composition. In the absence of disturbance, a gradual conversion of upland areas to peatland may take place in southeastern Labrador through a continual accumulation of organic material and paludification of the site (Foster and King, 1983; Wright, 1981), a process documented elsewhere in North America (Drury, 1956; Heinselman, 1963; Viereck, 1970). Although there is some debate in the literature concerning the role of fire in the paludification process (e.g. Auer, 1933: Heinselman, 1972: Walter, 1977), it is apparent that in southeastern Labrador fire retards the conversion of upland to peatland (Foster, 1984b). By reducing the thick insulating mat of organic material and eliminating the Sphagnum cover, fire recycles nutrients and alters the local environment regime to favor early successional species and productive forest growth.

\section{SPHAGNUM SUCCESSION IN PEATLANDS}

\section{Mud Bottoms on Raised Bogs and Poor Fens}

Water-filled pools of both poor fens and bogs in southeastern Labrador are covered with sparse vegetation that is remarkably similar because of the oligotrophic and acidic nature of both environments (Foster and King, 1984; Glaser and Foster, 1984). Nuphar variegatum is scattered in deep water on bogs and may be associated with Sparganium angustifolium and Carex aquatilis on fens. In shallow bog pools Scirpus cespitosus, Carex limosa, Andromeda glaucophylla, and Chamaedaphne calyculata predominate, whereas in the fens where nutrient availability is greater, Menyanthes trifoliata and Betula michauxii are also found. The pool floors are composed of a matrix of flocculent fine-grained plant detritus interspersed with fragments of woody material, primarily roots, stems, and twigs of shrubs (Foster and King, 1984).

Any significant drop in the water level of pools may expose the pool floor, presenting mud bottoms (sensu Sjors, 1948) open to colonization by such species as the hydrophilic bryophytes Cladopodiella fluitans and Gymnocolea inflata (Foster and King, 1983). If this habitat remains available, the vegetation may in time exhibit a succession of species, as the environment changes (generally to progressively drier conditions) and robust species (predominantly Sphagnum spp.) overtop smaller hepatics.

Pool water levels can drop for a variety of reasons, including local physical or biotic processes or more regional changes, e.g. alteration of the precipitation/evaporation balance. Two processes that operate on peatlands across southeastern Labrador are described below (cf. Foster et al., 1983; Foster and King, 1984). On bogs and fens the coalescence of adjacent pools as a result of degradation of the intervening ridge can result in the exposure of extensive mud bottoms. In a process similar to that described for the Silver Flowe in Scotland (Boatman and Tomlinson, 1973, 1977; Boatman et al., 1981), the size of individual pools on patterned peatlands in Labrador increases by means of the coalescence of adjacent pools. Where the ridge degrades between pools on slightly different slope positions, the higher pool drains to the lower.

On raised plateau bogs drainage streams often develop leading from the edge of the plateau across the rand (sensu Birks and Birks, 1980) to the margin of the peatland (cf. Damman, 1979). With time these streams erode headward towards the center of the plateau by means of the breakdown of ridges and "capture" of pools. As gaps in the ridges are eroded, the pools are gradually drawn down and emptied, and a small peat valley with a mud floor takes form (Foster et al., 1983).

The end result of both processes is the exposure of the unvegetated pool bottom, with an abrupt transition to the thick vegetation cover at the former margin of the pool. The open habitat is a loose, well-decomposed ooze.

The spatial distribution of species covering older mud bot- 
toms indicates, at least in part, the temporal succession onto these areas, and is in accordance with the species' tolerance of water-logging. Farthest out onto the former pool bottom (and at lowest elevation) is the hepatic Cladopodiella fluitans. This species is usually followed on slightly higher locations by Sphagnum lindbergii and then by other Sphagnum spp. (including $S$. papillosum, $S$. magellanicum, $S$. rubellum) in a somewhat variable pattern.

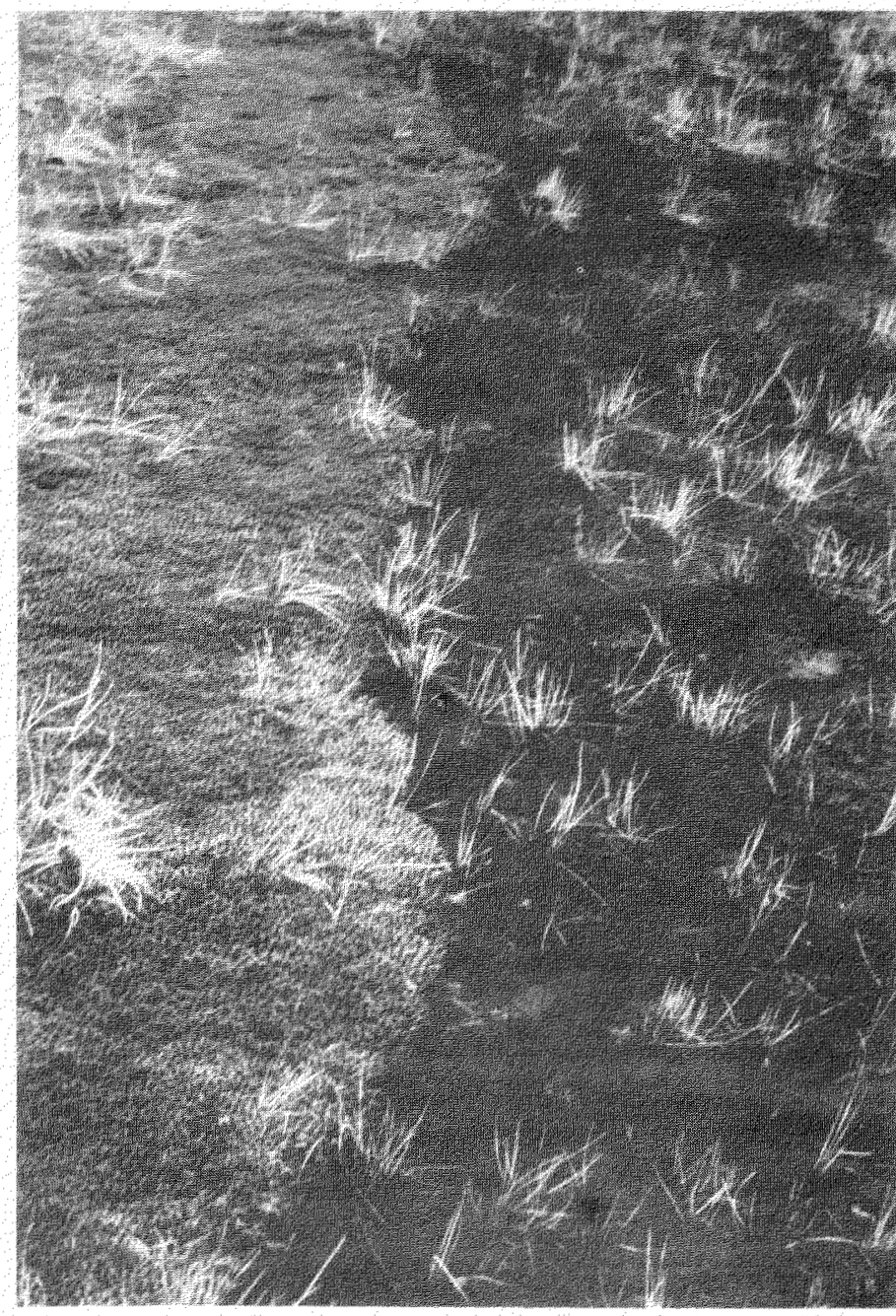

FIG. 3. Continuous wave of Sphagnum lindbergii spreading across a bog mud bottom that is covered with a thin layer of Cladopodiella fluitans and scattered shoots of Carex limosa.

Sphagnum lindbergii forms an abrupt border with the mat of Cladopodiella fluitans (Fig. 3). The loose, homogeneous carpet of Sphagnum lindbergii encroaches in a wave-like fashion over the smaller bryophytes. In vertical section the carpet is $1-2 \mathrm{~cm}$ thick at front and thickens behind. In places, a discontinuous layer of poorly preserved Cladopodiella fluitans is apparent between the Sphagnum and the amorphous mud bottom (Fig. 4). The Sphagnum lindbergii is appressed to the surface and exhibits a strong component of horizontal growth. The carpet is water-saturated and only slightly raised above the mud surface.

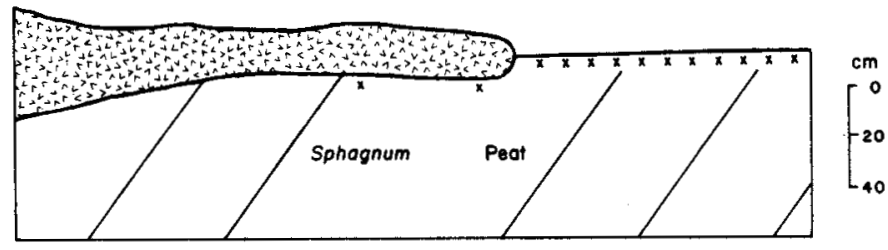

[3] Sphagnum lindbergil $\quad\left[\begin{array}{ll}x \\ 1\end{array}\right.$ Cladopodiallo fluitans

FIG. 4. Cross-section through an expanding cover of Sphagnum lindbergii. This species forms low and continuous mats and exhibits little tendency to form extensive peat deposits.

\section{Bog Hummocks}

The elevated portion of the bog surface is built up by accumulations of Sphagnum fuscum peat, and the surface cover consists of Sphagnum fuscum, Cladonia stellaris, and $C$. rangiferina (Table 1). The lichens are apparently more tolerant of desiccation than the Sphagnum and are located on higher, more exposed hummock surfaces. The podetia of these species are $\sim 8-15 \mathrm{~cm}$ long, and grade from active growth regions at the top to senescent and decaying areas towards the base, which rests on well preserved Sphagnum fuscum peat (Fig. 5). Throughout the ombrotrophic peatlands investigated in southeastern Labrador, the lichen layer is of similar thickness and is always found growing on Sphagnum peat (cf. Glaser and Foster, 1984).

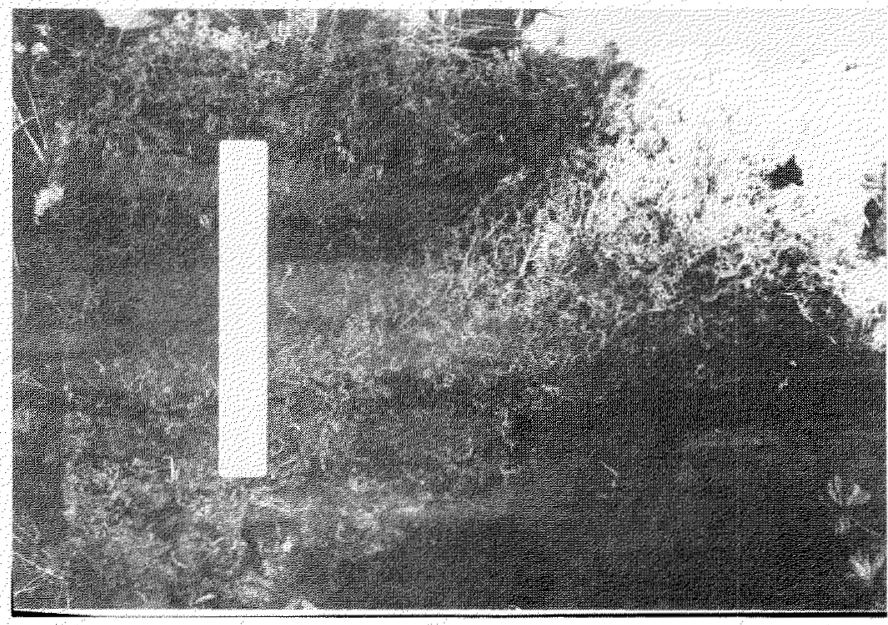

FIG. 5. Profile through a bog hummock illustrating the stratigraphic sequence: humified Sphagnum fuscum peat - Cladonia stellaris - Sphagnum fuscum, from lower right to upper left. The ruler is $15 \mathrm{~cm}$ long.

The living Sphagnum fuscum on the surface is generally sharply separated from the adjacent lichens. Stratigraphic investigation suggests that the abrupt demarcation between moss and lichen layers is a result of the faster growth rate of Sphagnum fuscum, which allows it to overgrow the Cladonia spp. (Fig. 6). As the Sphagnum grows obliquely upward it forms an advancing wedge that rests on an overgrown wedge of lichen. Through time the representative area of lichen cover decreases as the Sphagnum fuscum expands.

This major shift in vegetative cover is most likely to be 


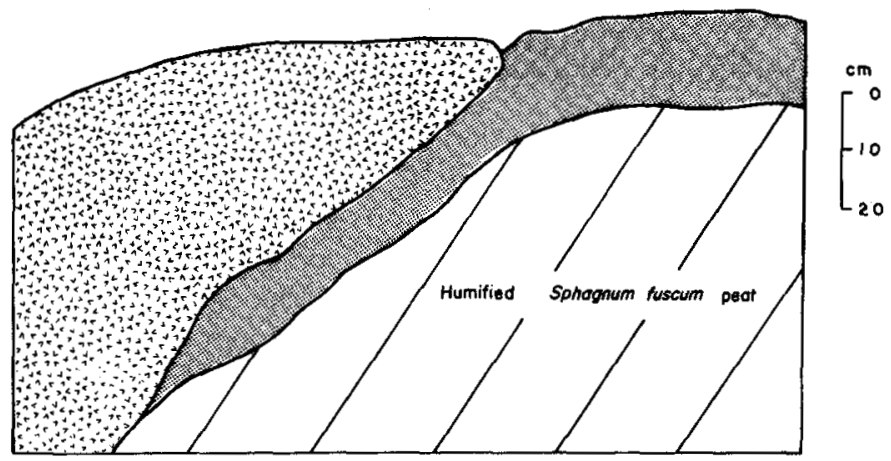

Esphagnum fuscum Clodonia stellaris

FIG. 6. Wedge of Sphagnum fuscum overgrowing Cladonia stellaris on a hummock summit. Sphagnum fuscum exhibits a strong component of vertical growth.

caused by a significant disturbance of the bog environment, although normal cyclic successional processes may also be responsible (sensu Osvald, 1923; Aaby, 1978). The water balance of a raised bog is highly sensitive to climatic change because a bog receives all its water supply from atmospheric precipitation. A decrease in the water table, produced either by increased temperature and hence increased evapotranspiration or by decreased precipitation, would be detrimental to Sphagnum growth and would favor the lichen cover. An opposite trend in climatic conditions would shift the balance the other way. Thus the stratigraphic sequence Sphagnum lichen - Sphagnum could represent a warmer, drier climate, followed by a reversal.

A second factor, fire, operates at least locally on bogs in southeastern Labrador (Foster, 1983a). Fire burns selectively along ridge and hummock tops among the lichens, the ericaceous shrubs, and the conifers and their litter, leaving the moister hollows unburned. Sphagnum fuscum seldom burns because of its high moisture content, but it may be killed by scorching. On scorched, dead Sphagnum a sequence occurs that is somewhat similar to the post-fire succession of cryptogams on the uplands (cf. Foster, 1984b). Polytrichum strictum invades or resprouts immediately following fire, accompanied by Cladonia sulphurina, $C$. gracilis, C. coccifera, $C$. macrophylla, and other cup-type lichens. These species are followed in turn by Cladonia mitis and $C$. uncialis, and finally by the long-term dominants $C$. rangiferina and $C$. stellaris. As the overall hydrology of bog and hummock are not altered by fire, in time unburned hummocks of Sphagnum fuscum can expand, overtop the lichens, and resume their pre-fire abundance. The presence of charcoal beneath Cladonia stellaris in some stratigraphic sequences, along with field observations of stages in this post-fire succession, establish fire as a locally important factor. However, the relatively low frequency of fire in southeastern Labrador, and the ubiquitous nature of the recurrence horizon (layers of decomposed peat alternating with relatively undecomposed peat, cf. Barber, 1981) in bogs across southeastern Labrador, suggest that a regional factor such as climate must also be responsible.

\section{DISCUSSION}

The pattern of vegetation development following perturbation is often a result of local environmental change. The sequence of plants that invade and occupy a site depends on the life-history characteristics of the locally available pool of species and the outcome of interspecific interactions.

In mire communities and some upland communities of southeastern Labrador, Sphagnum species are found in the later stages of vegetation development and form the dominant ground cover for extended periods of time, when the community is apparently in equilibrium with the environment. By virtue of their ability to modify the local environment, compete successfully with other bryophytes, and grow rapidly under conditions detrimental to other species, they retain a dominant position in the community.

It is often misleading to infer either direction of succession or a species' position in succession from the distribution of species within a community at one point in time (cf. Vitt and Slack, 1975; Egler, 1977; McIntosh, 1980). It is preferable to have some understanding of past population dynamics of the species, its growth rate relative to other species, and its historical abundance, in order to explain the vegetative patterns in the present landscape. The stratigraphic record of Sphagnum succession in southeastern Labrador supports inferences drawn from the analysis of modern communities. There exists a sharp delineation between the spreading mats of particular Sphagnum spp. and adjacent cryptogams in the three habitats described. The radial growth of the Sphagnum carpets suggests the advancement of the species over the adjoining ground cover.

\section{CONCLUSION}

Stratigraphy demonstrates that Sphagnum growth in the habitats studied is often oblique, as it grows up and over the other slower-growing cryptogams. The degree of oblique growth is determined by the nature of the environment and by the growth form of the particular species. Sphagnum fuscum, which grows in compact, dense hummocks in a relatively dry environment, is one of the most important peat-building Sphagnum species. Its tight growth form, dense branching, and strongly vertical component of growth enable it to maintain a sharp margin with adjoining species.

Sphagnum girgensohnii grows under moist, shaded conditions within woodlands where peats are shallow (Horton $e t$ al., 1979). Its growth form is more lax and less ramifying than $S$. fuscum, and therefore its growth is more sprawling. It spreads horizontally over the feather mosses, and only slowly increases the depth of the organic layer. Extensive low hummocks of nearly pure populations of Sphagnum girgensohnii form a continuous carpet in many older forests in southeastern Labrador, similar to those noted elsewhere in the Canadian boreal forest (Horton et al., 1979).

Of the three species, Sphagnum lindbergii least displays the vertical component of growth, and it contributes little to peat accumulations. Occupying aquatic and water-saturated habitats, it forms loose, floating carpets. The slightly elevated 
carpets spread horizontally over wet mud surfaces and appressed hepatics, and exhibit little tendency to climb and overtop more robust species.

\section{ACKNOWLEDGEMENTS}

Assistance with the field work and discussions of the problem of Sphagnum succession were generously provided by G. King, P. Glaser, P. Pakarinen, and H.E. Wright. Critical reading of the manuscript and numerous helpful additions were provided by $\mathbf{P}$. Glaser, J. Janssens, C.R. Upton, D. Vitt, and H.E. Wright. R. Ireland, J. Janssens, and C. Wetmore provided assistance with the cryptogam taxonomy. Research support was derived from grants from the Smithsonian Institution (through W. Fitzhugh), National Geographic Society, National Science Foundation (DPP 81-00124, DEB 79-22142), and U.S. Department of Energy (through T. Webb of Brown University).

\section{REFERENCES}

AABY, B. 1978. Cyclic changes in climate during 5,500 years, reflected in Danish raised bogs. Danish Meteorological Institute. Climatological Papers No. 4:18-26.

AHTI, T. 1961. Taxonomic studies on reindeer lichens (Cladonia, subgenus Cladina). Annales Botanici Societas (Vanamo) 32:1-160.

ANDRUS, R.E. 1974. The Sphagna of New York State. PhD thesis, State University of New York, Syracuse, N.Y. 389 p.

AUER, V. 1933. Peat bogs of southeastern Canada. In: Bulow, K.V. (ed.). Handbuch der Moorkunde. Berlin: Von Gebruder Borntraeger. 141-221.

BARBER, K.E. 1981. Peat Stratigraphy and Climate Change. A Paleoecological Test of the Theory of Cyclic Peat Bog Regeneration. Rotterdam: A.A. Balkema. 268 p.

BIRKS, H.J.B. and BIRKS, H.H. 1980. Quaternary Palaeoecology. London: Edward Arnold Publishers. 374 p.

BIRSE, E.M. 1958. Ecological studies on growth-form in bryophytes. III. The relationship between growth-form of mosses and ground-water supply. Journal of Ecology 46:9-27.

BOATMAN, D.J. and TOMLINSON, R.W. 1973. The Silver Flowe I. Some structure and hydrological features of Brishie Bog and their bearing on pool formation. Journal of Ecology 61:653-666.

1977. The Silver Flowe II. Features of the vegetation and stratigraphy of Brishie Bog and their bearing on pool formation. Journal of Ecology 65:531-546.

BOATMAN, D.J., GOODE, D.A. and HULME, P.D. 1981. The Silver Flowe III. Pattern development on Long Loch B and Craigeazel Mires. Journal of Ecology 69:879-912.

CLYMO, R.S. 1963. Ion exchange in Sphagnum and its relation to bog ecology. Annals of Botany 27:309-324.

1964. The origin of acidity in Sphagnum bogs. Bryologist 67:427-431 .

COOPER, W.S. 1912. The ecological succession of mosses, as illustrated upon Isle Royale, Lake Superior. Plant World 15:197-213.

DAMMAN, A.W.H. 1979. Geographic patterns in peatland development in eastern North America. Proceedings, International Symposium on the Classification of Peat and Peatlands. Hyytiälä, Finland, 17-21 September 1979. International Peat Society. 42-57.

DRURY, W.H. 1956. Bog flats and physiographic processes in the Upper Kuskokwim River Region, Alaska. Contributions from the Gray Herbarium 178. $127 \mathrm{p}$.

EGLER, F.E. 1977. The Nature of Vegetation. Its Management and Mismanagement. Bridgewater, CT: Connecticut Conservation Association. 527 p.

FOSTER, D.R. 1983a. The history and pattern of fire in the boreal forests of southeastern Labrador. Canadian Journal of Botany 61:2459-2471.

1983b. The phytosociology, fire history, and vegetation dynamics of the boreal forests of southeastern Labrador, Canada. PhD thesis. University of Minnesota, Minneapolis, MN. 213 p.

1984a (in press). Phytosociological description of the forest vegetation of southeastern Labrador. Canadian Journal of Botany 62. 1984b (in press). Vegetation development following fire in the Black Spruce-Pleurozium forests of S.E. Labrador. Journal of Ecology 73.

and KING, G.A. 1984. Landscape features, vegetation, and the developmental history of a patterned fen in southeastern Labrador, Canada. Journal of Ecology 72:115-143.

GLASER, P.G. and WRIGHT, H.E. 1983. Origins of string patterns in boreal peatlands. Nature 306:256-258.

GIMINGHAM, C.H. and BIRSE, E.M. 1957. Ecological studies on growthform in bryophytes. 1. Correlations between growth-form and habitat. Journal of Ecology 45:533-545.

GLASER, P.H. and FOSTER, D.R. 1984 (in press). The vascular flora on raised bogs in southeastern Labrador and its phytogeographic significance. Canadian Journal of Botany.

HALE, M.E. and CULBERSON, W.L. 1970. A fourth checklist of the lichens of the Contintental United States and Canada. Bryologist 73:499-533.

HARE, F. 1959. A photo-reconnaissance survey of Labrador - Ungava. Mimeo 6. Geographical Branch, Department of Mines and Technical Surveys, Ottawa. $83 \mathrm{p}$.

HEILMAN, P.E. 1966. Change in distribution and availability of nitrogen in forest succession in northern slopes in Interior Alaska. Ecology 47:825-831.

HEINSELMAN, M.L. 1963. Forest sites, bog processes, and peatland types in the Glacial Lake Agassiz Region, Minnesota. Ecological Monographs 33:327-374.

1970. Landscape evolution, peatland types, and the environment in the Lake Agassiz Peatlands Natural Areas, Minnesota. Ecological Monographs 40:235-261.

1972. Boreal peatlands in relation to environment. Heidelberg: Springer-Verlag. Ecological Studies 10:93-103.

1973. Fire in the virgin forests of the Boundary Waters Canoe Area, Minnesota. Quaternary Research 3:329-382.

HORTON, D.H., VITT, D.H. and SLACK, N.G. 1979. Habitats of circumboreal-subarctic Sphagna: I. A quantitative analysis and review of species in the Caribou Mountains, northern Alberta. Canadian Journal of Botany 57:2283-2317.

IRELAND, R.R., BIRD, C.D., BRASSARD, G.R., SCHOFIELD, W.B. and VITT, D.H. 1980. Checklist of the Mosses of Canada. National Museums of Canada, Publications in Botany, No. 8. 75 p.

LEWIS, F.J. and DOWDING, E.S. 1926. The vegetation of retrogressive changes of peat areas ("Muskegs") in central Alberta. Journal of Ecology 14:317-341.

and MOSS, E.H. 1928. The vegetation of Alberta. II. The swamp, moor, and bog forest vegetation of central Alberta. Journal of Ecology 16:19-70.

McINTOSH, R.P. 1980. The relationship between succession and the recovery process in ecosystems. In: Cairns, J. (ed.). The Recovery Process in Damaged Ecosystems. Ann Arbor, MI: Ann Arbor Science Publications $11-62$.

MOIZUK, G.A. and EIVINGSTON, R.B. 1966. Ecology of red maple in a Massachusetts upland bog. Ecology 47:942-950.

MUELLER-DOMBOIS, D. and ELLENBERG, H. 1974. Aims and Methods of Vegetation Ecology. New York: Wiley. 547 p.

OSVALD, H. 1923. Die Vegetation des Hochmoores Komosse. Svenska Vaxtsociologiska Sallskapets Handlingar (Uppsala) 1:1-436.

PAKARINEN, P. and RINNE, R.J.K. 1979. Growth rates and heavy metal concentrations of five moss species in paludified spruce forests. Lindbergia 5:77-83.

ROSSWELL, T., VEUM, A.K. and KARENLAMPI, L. 1975. Plant litter decomposition at Fennoscandian Tundra Sites. Ecological Studies \#16. Fennoscandian Tundra Ecosystems. New York: Springer-Verlag. 268-278.

SIRÉN, G. 1955. The development of spruce forests on raw humus sites in $\mathbf{N}$. Finland and its ecology. Acta Forestalia Fennica 62:1-363.

SJORS, H. 1948. Mire vegetation in Bergslagen, Sweden. (English Summary). Acta Phytogeografica Suecica 21:1-229.

STOTLER, R. and CRANDALL-STOTLER, B. 1977. A checklist of the liverworts and hornworts of North America. Bryologist 80:405-428.

SWAN, J.M.A. and GILL, A.M. 1970. The origins, spread, and consolidation of a floating bog in Harvard Pond, Petersham, Massachusetts. Ecology 51:829-840. 
TAMM, C.O. 1953. Growth, yield and nutrition in carpets of a forest moss (Hylocomium splendens). Meddelanden Fran Statens Skogs Forskningsinstitut. Band 43. NR1:1-139.

TANSLEY, A.G. 1949. The moss or bog formation. Ch. 34 in: The British Isles and their Vegetation. Vol. II. Cambridge: Cambridge University Press. 1108-1137.

VIERECK, L.A. 1966. Plant succession and soil development on gravel outwash of the Muldrow Glacier, Alaska. Ecological Monographs 36:181-199.

1970. Forest succession and soil development adjacent to the Chena River in interior Alaska. Ecological Monographs 36:181-199.

VITT, D.H. and SLACK, N.G. 1975. An analysis of the vegetation of Sphagnum-dominated kettle-hole bogs in relation to environmental gradients. Canadian Journal of Botany 53:2776-2795.

VITT, D.H., ACHUFF, P. and ANDRUS, R.E. 1975. The vegetation and chemical properties of patterned fens in the Swan Hills, North Central Alberta. Canadian Journal of Botany 53:2776-2795.

WAKSMAN, S.A. 1930. Chemical composition of peat and the role of microorganisms in its formation. American Journal of Science 19:32-53.

WALKER, D. 1970. Direction and rate in some British post-glacial hydrosers. In: Walker, D. and West, R.G. (eds.). Studies in the Vegetation History of the British Isles. Cambridge: Cambridge University Press. 43-57.

WALTER, H. 1977. The oligotrophic peatlands of Western Siberia - the largest Peino-Helobrome in the world. Vegetatio Acta Geobotanica 34:167-178.

WENNER, C.G. 1947. Pollen diagrams from Labrador. Geografiska Annaler H. 3-4: 137-374.

WRIGHT, H.E. 1981. The role of fire in land/water interactions. In: Mooney, H.A., Bonnicksen, T.M., Christensen. N.L., Lotan, J.E., and Reiners, W.A. (eds.). Fire Regimes and Ecosystem Properties. Washington, D.C.: U.S. Dept. of Agriculture. General Technical Report WO-26:421-454. 